\title{
PENGEMBANGAN 24 DESTINASI WISATA BAHARI KABUPATEN ENDE
}

\author{
Josef Alfonsius Gadi Djou \\ Fakultas Ekonomi Universitas Flores \\ Email: josefdevigadidjou@hotmail.com
}

\begin{abstract}
There are 24 marine tourism destinations in Ende District that have not been managed well enough. To improve tourism development, some management strategies should be taken by stakeholders. First, the government should make some policies that give opportunities and easy access to stakeholders. Scond, the government should make a development planning for the potential destinations. Third, they should make plans that would give information about the most potential destination. Fourth, the government and marine communities should prepare human resource in management. At last, the government should promote those marine tourism destinations continuosly.
\end{abstract}

Key words: Strategy, Development, Human resources

\section{ABSTRAK}

Terdapat 24 destinasi wisata bahari di Kabupaten Ende yang belum dikelola dengan baik belum. Untuk meningkatkan kinerjanya, beberapa strategi manajemen harus diambil oleh para pemangku kepentingan. Kedua, pemerintah harus membuat perencanaan pengembangan destinasi potensial. Ketiga, mengatur rencana akan memberikan informasi tujuan yang paling potensial. Keempat, pemerintah dan kelautan masyarakat harus mempersiapkan sumber daya manusia di tingkat manajerial. Akhirnya, pemerintah harus memproomosikan tujuan tersebut wisata bahari terus menerus.

Kata kunci: Strategi, Pembangunan, Sumberdaya manusia 


\section{PENGANTAR}

Indonesia dikenal sebagai negara kepulauan terbesar yang wilayahnya terbentang dari Sabang hingga Merauke atau dari Talaud hingga Rote. Indonesia diakui sebagai salah satu negeri yang elok dengan berbagai keindahan alamnya, tidak hanya di darat, juga di laut. Di Indonesia bertebar beraneka ragam ekosistem laut dan pesisir. Ada terdapat banyak pantai berpasir indah di negeri ini yang menakjubkan bagi yang melihatnya. Ada juga banyak gua, laguna, estuari, hutan mangrove, padang lamun, rumput laut, dan terumbu karang yang menghiasi negeri ini. Semuanya indah dan perawan (pristine, unspoiled).

Indonesia juga memiliki enam dari sepuluh ekosistem terumbu karang terindah dan terbaik di dunia. Ada Raja Ampat, Wakatobi, Taka Bone Rate, Bunaken, Karimun Jawa, dan Pulau Weh yang terderet dalam sepuluh ekosistem terumbu karang yang dikeluarkan oleh World Tourism Organization. Indonesia sebagai negara kepulauan berpotensi besar untuk mengembangkan potensi wisata bahari. Keragaman hayati dan kebhinekaan sosial budaya memiliki keunikan dan daya tarik bagi wisatawan nusantara dan mancanegara. Pengembangan potensi wisata bahari memiliki arti strategis dalam pengembangan budaya bahari, usaha multisektor, ekonomi daerah, dan penguatan peran serta masyarakat.

Potensi-potensi wisata di Pulau Flores Nusa Tenggara Timur seperti pulau Komodo di Kabupaten Manggarai Barat dan Danau Tiga Warna Kelimutu di Kabupaten Ende. Selama ini yang dikenal oleh wisatawan mancanegara (wisman) hanya dua objek wisata di Pulau Flores, padahal di kabupaten lain, selain kedua kabupaten itu, masih banyak objek wisata lain. Dari arah barat Pulau Flores, objek wisata itu adalah sebagai berikut: Pulau Komodo di Kabupaten Manggarai Barat, Danau Ranamese dan Pemandangan Indah di Gunung Anak Ranaka Kabupaten Manggarai Timur, Taman Wisata Alam Tujuh Belas Pulau di Riung Kabupaten Ngada, Danau Tiga Warna Kelimutu di Kabupaten Ende, Taman Wisata Alam Gugus Pulau Teluk Maumere di Kabupaten Sikka, Devosi Prosesi Jumad Agung atau Semana Santa di Kabupaten Flores Timur, dan Atraksi Langka Perburuan Ikan Paus Nelayan Lamalera di Kabupaten Lembata.

Kabupaten Ende yang berada di Pulau Flores, Provinsi Nusa Tenggara Timur memiliki berbagai potensi wisata bahari yang dapat lebih dikembangkan menjadi daya tarik bagi wisatawan, baik wisatawan nusantara maupun wisatawan asing. Kabupaten Ende dengan luas 2.046,60 km2 dan memiliki garis pantai sepanjang $111 \mathrm{mil}$ atau $205,572 \mathrm{~km}$ terbelah dari pesisir utara panjang $60 \mathrm{mil}$ atau 111,120 $\mathrm{km}$ dan pesisir selatan sepanjang $51 \mathrm{mil}$ atau 94,452 km ditengah dari Pulau Flores.

Data kunjungan wisatawan ke Taman Nasional Kelimutu di Kabupaten Ende dari tahun 2006 sampai dengan 2010 adalah sebagai berikut.

Tabel 1

Pengunjung Taman Nasional Kelimutu Tahun 2006 sampai dengan 2010

\begin{tabular}{|l|r|r|r|r|}
\hline No. & \multicolumn{1}{|c|}{ Tahun } & Wisman & Wisnu & \multicolumn{1}{c|}{ Jumlah } \\
\hline 1 & 2006 & 3.546 & 6.225 & 9.771 \\
\hline 2 & 2007 & 3.671 & 7.469 & 11.140 \\
\hline 3 & 2008 & 5.299 & 11.266 & 16.495 \\
\hline 4 & 2009 & 7.327 & 16.775 & 24.102 \\
\hline 5 & 2010 & 7.111 & 17.704 & 24.815 \\
\hline \multicolumn{5}{|r|}{} \\
\hline
\end{tabular}

Ende 2011

Data di atas memperlihatkan bahwa yang menjadi prioritas kunjungan wisatawan ke Kabupaten Ende adalah Taman Nasional Kelimutu. Pengunjung wisata bahari belum ada.

Tulisan ini bertujuan untuk mencari strategi bagi pengembangan potensi wisata bahari di Kabupaten Ende; potensi wisata bahari diharapkan dapat menjadi penopang perekonomian masyarakat Kabupaten Ende; pengembangan potensi wisata bahari 
secara terencana dan bervisi untuk jangka waktu panjang bertujuan bagi kemajuan pariwisata Kabupaten Ende. Menurut Sayid Abdul Karim dalam SumbawaNews.com (15 Januari 2009), dengan memahami berbagai potensi dan hambatan kultural yang ada pada masyarakat setempat, potensi wisata di daerah kurang berkembang dan belum dapat dimaksimalkan. Pengembangan pariwisata bukan hanya merupakan tugas pemerintah. Akan tetapi, juga pelaku bisnis pariwisata diharapkan dapat berperan aktif dalam mengembangkan destinasi dan melaksanakan strategi pemasaran yang tepat, efisien, dan efektif, terutama bagi objek daya tarik wisata (ODTW) yang potensial untuk dipasarkan. Dengan strategi tersebut, daerah kurang berkembang akan menjadi daerah destinasi pariwisata yang mempesona.

Visi dan misi wisata bahari (Hermantoro, 2009: 3) adalah "Indonesia dalam waktu 10 tahun menjadi tujuan wisata bahari terkemuka di Kawasan Asia Pasifik". Misi wisata bahari adalah (1) memberikan pelayanan terbaik bagi wisatawan di alam kebaharian Indonesia; (2) menciptakan iklim kondusif bagi investasi industri wisata bahari; (3) menciptakan keterpaduan pengembangan pariwisata bahari yang berkelanjutan; (4) mengembangkan produk wisata bahari dengan pola kemitraan diantara pelaku wisata bahari.

Strategi penjabarannya adalah (1) pengembangan terpadu kawasan wisata bahari; (2) penataan sistem informasi, promosi, dan pemasaran; (3) pengembangan usaha pariwisata; (4) penataan sistem pelayanan dan perizinan; (5) penataan sistem kepelabuhan; (6) konservasi lingkungan; dan (7) pengembangan usaha berbasis masyarakat. M. Faried Moertolo (Kompas, 06 Juni 2011) mengatakan bahwa pemerintah daerah harus bergerak cepat, terutama dalam usaha meningkatkan kualitas sumber daya manusia di bidang pariwisata. Akomodasi dan transportasi harus dipikirkan supaya wisatawan merasa nyaman.

Beberapa definisi operasional yang dipakai dalam tulisan ini adalah sebagai berikut. Strategi adalah rencana yang cermat mengenai kegiatan untuk mencapai sasaran khusus. Pengembangan adalah proses, cara membangun secara bertahap dan teratur yang menjurus ke sasaran yang dikehendaki. Potensiadalah kemampuan yang mempunyai kemungkinan untuk dikembangkan. Wisata adalah kegiatan perjalanan yang dilakukan oleh seseorang atau sekelompok orang dengan mengunjungi tempat tertentu untuk tujuan rekreasi, pengembangan pribadi, atau mempelajari keunikan daya tarik wisata yang dikunjungi dalam jangka waktu sementara.

\section{Konsep dan Sistem Pariwisata}

Pariwisata adalah sesuatu hal yang selalu dinamis, selalu ada pembaharuan dan adaptasi sesuai dengan situasi dan kondisi yang dihadapi. Pariwisata merupakan suatu kegiatan yang memiliki banyak fenomena. Pada prinsipnya pariwisata bertalian dengan fenomena yang muncul berkaitan dengan perjalanan dan menginap dari orang yang melakukan kunjungan dari suatu daerah, terutama bertujuan untuk mengisi waktu luang dan rekreasi (Pearce, 1989:16-20). Dengan demikian pariwisata merupakan aktivitas manusia yang mencakup tingkah laku, penggunaan sumber daya dalam berinteraksi dengan masyarakat, ekonomi dan lingkungan (Bull: 1985 dalam Cempora: 2007). Aspek-aspek dalam pariwisata tersebut saling berhubungan dan hubungan tersebut dijabarkan dalam sistem pariwisata.

Sistem pariwisata digambarkan sebagai hubungan antara permintaan dan penawaran (Gunn, 2002). Pasar wisatawan merupakan sisi permintaan (demand) dan aspek penawaran (supply) adalah perjalanan dan destinasi. Dalam Mill dan Morrison (1985: 99) sistem pariwisata terdiri dari empat aspek penting yaitu market (pasar wisatawan), travel (perjalanan), destination (tujuan wisata) dan marketing (pemasaran). Pasar wisatawan menggunakan pendekatan perilaku konsumen dengan penekanan pada faktor eksternal dan internal. Perjalanan merupakan deskripsi dari arus wisatawan dan moda transportasi yang digunakan. 
Destinasi wisata tetap mengacu pada prosedur-prosedur yang harus diikuti dalam hal perencanaan, mengatur, mengembangkan dan memberikan pelayanan terhadap aktivitas wisata. Pemaparan terkait dengan pemasaran produk dan jasa daerah tujuan wisata dengan tetap mengacu pada efektivitas.

Kegiatan pariwisata merupakan sebuah interaksi sosio-kultural, sebab didalamnya terkandung interaksi antara host (tuan rumah) dengan guests (wisatawan). Interaksi diantara mereka akan terlaksana dalam konteks pencarian dan penyediaan pengalaman/ perbedaan dan lebih nyata lagi dilakukan atas dasar pertukaran ekonomi. Konteks interaksi membawa akibat pada hadirnya tingkahlaku yang khas, baik yang dialami wisatawan atau diterima oleh masyarakat setempat.

\section{Pariwisata Bahari}

Wisata bahari adalah bentuk wisata yang menggunakan atau memanfaatkan potensi lingkungan pantai dan laut sebagai daya tarik utama. Konsep wisata bahari didasarkan pada view, keunikan alam, karakteristik ekosistem, kekhasan seni dan budaya serta karakteristik masyarakat sebagai kekuatan dasar yang dimilikinya (Sero, 2010: 19). Menurut Fandeli (1996: 50), wisata bahari adalah wisata yang objek dan daya tariknya bersumber dari bentang laut (seascape) maupun bentang darat pantai (coastal landscape).

Dalam hubungan dengan aktivitas wisata alam pantai dan bahari maka secara umum kegiatan wisata di objek wisata alam dapat diklasifikasikan kedalam 2 (dua) kelompok, yaitu 1) wisata perairan atau wisata bahari; dan 2) wisata daratan. Aktivitas bentang laut, yaitu berenang, memancing, bersampan yang meliputi berdayung, atau berlayar, menyelam yang meliputi diving dan snorkeling, berselancar yang meliputi selancar air dan selancar angin serta berperahu parasut (parasailing). Aktivitas bentang darat, yaitu rekreasi berupa olahraga susur pantai, bersepeda, panjat tebing pada dinding terjal pantai dan menelusuri gua pantai. Selain itu dapat pula dilakukan aktivitas bermain layang-layang, berkemah, berjemur, berjalanjalan melihat pemandangan, berkuda atau naik dokar pantai.

Menurut Fandeli (1995: 89), wisata perairan atau wisata bahari (didalamnya termasuk wisata pantai) adalah kegiatan wisata seperti berenang, memancing (fishing), menyelam (diving dan snorkeling), berlayar (sailing), berselancar (surfing), ski laut (skiing), berjemur, rekreasi pantai, photografi bawah air, canoeing, dan lain-lain. Adapun kegiatan menikmati keindahan dan keanekaragaman hayati potensi laut dapat dilakukan dengan dua cara, yaitu (1) pada perairan dangkal dengan menggunakan perahu yang lantainya atau bagian dinding bawah perahu itu terdiri atas gelas kaca tembus pandang; dan (2) menggunakan perlengkapan menyelam khususnya untuk tempat-tempat yang dalam dan tidak mungkin dapat dilihat dengan perahu gelas kaca tembus pandang.

Dalam kegiatan wisata pantai, terdapat berbagai kriteria standar yang harus dipenuhi. Kriteria standar ini terdiri atas kriteria fisik, sosial, ekonomi dan budaya. Aktivitas kegiatan wisata bawah laut seperti diving dan snorkeling harus ditunjang dengan parameter-parameter dari pariwisata bawah laut, antara lain sebagai berikut (Sero, 2010: 21-22). Kecerahan perairan yaitu perairan yang cerah merupakan syarat utama yang harus dipenuhi dalam kegiatan ini, dimana semakin cerah suatu perairan semakin terlihat keindahan taman laut yang dinikmati oleh para wisatawan.

Tutupan terumbu karang, persentase tutupan terumbu karang merupakan syarat utama dalam pariwisata bahari, karena merupakan unsur utama dari nilai estetika taman laut yang akan dinikmati oleh para wisatawan. Jenis terumbu karang, semakin beragam jenis terumbu karang semakin banyak keindahan alam bawah laut yang dapat dinikmati oleh para wisatawan. Jenis ikan karang, daerah yang memiliki lebih dari 50 spesies dikategorikan sebagai daerah dengan jenis ikan karang sangat beragam. 
Kecepatan arus, kecepatan arus berkaitan dengan keamanan wisatawan dalam melaksanakan aktivitasnya. Dengan demikian kecepatan arus yang relatif lemah merupakan syarat ideal untuk kegiatan penyelaman. Kedalaman perairan, kedalaman perairan ditentukan oleh penetrasi sinar matahari kedalam perairan. Diasumsikan pertumbuhan karang laut umumnya sampai kedalaman 18 meter. Secara umum ragam daya dukung wisata bahari meliputi daya dukung ekologis, fisik, sosial, rekreasi. Penyediaan fasilitas secara umum pada objek wisata alam menurut Fandeli (1996: 50) terdiri atas.

Fasilitas, meliputi persyaratan lokal dan kemampuan pencapaian, peruntukkan dan tata guna tanah (land use), jalan umum, terminal dan parkir kendaraan, akomodasi, tempat rekreasi dan lain-lain. Prasarana, meliputi sistem dan jaringan air bersih, drainase air hujan, pembuangan limbah dan air kotor, suplai dan distribusi daya listrik, sistem dan jaringan komunikasi serta fasilitas transportasi jalan, terminal, jembatan, drainase, penerangan, dan sebagainya.

\section{Daya Tarik Wisata (DTW)}

Daya tarik wisata (DTW) terdiri atas; a) Daya tarik wisata ciptaan Tuhan YME seperti alam, flora dan fauna; b) Daya tarik wisata hasil karya manusia seperti museum, peninggalan purbakala, peninggalan sejarah, seni budaya, wisata agro, wisata tirta, wisata buru, wisata petualangan alam, taman rekreasi dan tempat hiburan. Daya tarik wisata (DTW) adalah sesuatu bentukan dan/ atau aktivitas dan fasilitas yang berhubungan, yang dapat menarik minat wisatawan atau pengunjung untuk datang kesuatu tempat/ daerah tertentu. Daya tarik wisata sangat berkaitan dengan travel motivation dan travel fashion, tanpa adanya daya tarik wisata di suatu daerah tertentu, maka kepariwisataan akan sulit untuk dikembangkan.

Secara garis besar daya tarik wisata dikategorikan dua jenis, yaitu (1) DTW alam; (2) DTW sosial budaya. Sementara daya tarik diklasifikasikan dalam tiga kelompok yaitu daya tarik alam, daya tarik budaya, dan daya tarik manusia (Marpaung, 2000: 80117). Produk pariwisata sebagai komponen penting dalam industri pariwisata mencakup tiga aspek yang dikenal dengan istilah triple A (atraksi, amenitas, dan aksesibilitas). Produk pariwisata dapat diartikan sebagai segala sesuatu yang dapat dijual sebagai komoditas pariwisata.

Atraksi/obyek dan daya tarik wisata adalah obyek yang memiliki daya tarik untuk dilihat, ditonton, dinikmati yang layak dijual ke pasar wisata. Seringkali atraksi ditafsirkan dalam dua komponen, yaitu sebagai obyek wisata (tourist object) dan atraksi wisata (tourist attraction). Atraksi wisata adalah sesuatu yang dapat dilihat melalui pertunjukan (shows) dan seringkali membutuhkan persiapan bahkan mengeluarkan pengorbanan untuk menikmatinya (membayar). Berbeda dengan obyek wisata (tourist object) yang dapat disaksikan tanpa perlu persiapan. Obyek wisata dan atraksi wisata keduanya termasuk dalam produk pariwisata. Dengan demikian DTW adalah segala macam obyek bergerak maupun tidak bergerak yang memiliki daya tarik wisata dan layak ditawarkan, dijual kepada pasar wisata, baik wisatawan domestik ataupun mancanegara.

Obyek pariwisata beserta segala atraksi yang diperlihatkan merupakan daya tarik utama bagi seseorang untuk berkunjung ke suatu tempat. Untuk itu keaslian dari obyek dan atraksi yang ditawarkan tetap harus dipertahankan dan dilestarikan. Disamping keaslian yang dipertahankan, juga perlu dipikirkan variasi obyek dan atraksi yang hendak dijual, agar tidak terkesan monoton. Disinilah pentingnya pengembangan diversifikasi produk di bidang pariwisata. Logikanya, keberhasilan pengembangan produk yang dilakukan akan berakibat meningkatnya kunjungan wisatawan yang berimbas pada lama tinggal dan besarnya pengeluaran wisatawan.

Disamping atraksi, yang termasuk dalam produk wisata lainnya adalah amenitas, yakni segala macam fasilitas yang menunjang kegiatan pariwisata. Di antaranya rumah 
makan, hotel, sarana komunikasi, papan informasi, penukaran uang (money changer) dan lainnya. Bahkan seringkali diperlukan jasa asuransi, khususnya bagi tipe wisata yang memiliki resiko kecelakaan tinggi. Keberadaan dan kelengkapan berbagai jenis fasilitas menjadi prasyarat mutlak bagi peningkatan kunjungan wisatawan pada suatu obyek wisata. Dengan kata lain meskipun obyek wisata yang dimiliki dinilai cukup bagus, namun bila tidak memiliki jaminan fasilitas yang memadai lambat laun tentu akan ditinggalkan wisatawan.

Aspek ketiga dalam produk wisata adalah aksesibilitas berupa sarana prasarana yang menyebabkan wisatawan dapat berkunjung ke sebuah destinasi (obyek wisata). Dalam konteks ini, sarana dan prasarana dibangun agar wisatawan dapat mencapai obyek dengan aman, nyaman dan layak. Inilah yang membedakan dengan domain ekonomi yang menyediakan sarana dan prasarana agar produk yang dijual dapat didistribusikan dan dapat dijangkau oleh konsumen. Sementara domain pariwisata sarana dan prasarana dibangun agar konsumen dapat mengunjungi obyek wisata sehingga konsumen dapat membeli produk tersebut. Dengan demikian aksesibilitas menyebabkan wisatawan mencapai obyek wisata dengan mudah, aman, dan nyaman/ layak.

Dari ketiga aspek produk wisata diatas, model pengembangan produk haruslah mempertahankan keasliannya agar dapat bersaing dengan daerah lainnya. Dengan kata lain, masing-masing obyek harus memiliki style tersendiri yang berbeda dengan obyek wisata lainnya. Style merupakan faktor penting dalam menentukan penjualan. Dalam pariwisata yang dikatakan product style yang baik adalah (1) daya tarik obyek itu sendiri; (2) memiliki perbedaan dengan obyek lainnya; (3) dukungan kondisi prasarana yang terpelihara dengan baik; (4) ketersediaan fasilitas something to see, something to do, something to buy; dan (5) dilengkapi dengan sarana prasarana lainnya (Fandeli, 2002 dalam Marpaung, 2009: 15-17).

\section{Strategi Pengembangan}

Perencanaan strategis di Indonesia mulai muncul dan banyak digunakan dalam organisasi publik di berbagai daerah seiring dengan ditetapkannya otonomi daerah. Perencanaan strategis muncul dan diminati berkaitan dengan semakin terbatasnya sumberdaya internal organisasi dan banyaknya tantangan eksternal yang mempengaruhi kinerja dan peran organisasi (Baiquni, 2004: 1). Alasan-alasan diperlukannya perencanaan strategis (Wardiyanto dan Baiquni, 2011: 97-98). Perencanaan strategis dapat menjadi panduan bagi organisasi pemerintahan untuk dapat melakukan tindakan yang bersifat antisipatif terhadap perubahan yang terjadi. Dengan begitu, kebijakan pemerintah tidak hanya sekedar bereaksi atau reaktif terhadap perubahan yang terjadi.

Perencanaan strategis dapat menjadi panduan bagi organisasi pemerintahan untuk membangun strateginya sebagai bagian penting organisasi yang berorientasi pada hasil. Kapabilitas dan sumber daya difokuskan secara optimal untuk mencapai hasil yang diinginkan. Perencanaan strategis dapat memberikan komitmen pada aktivitas dan kegiatan di masa mendatang. Perencanaan strategis memerlukan pengumpulan informasi secara menyeluruh untuk kemudian menyiapkan analisis atas berbagai alternatif dan implikasi yang dapat diarahkan pada masa mendatang.

Perencanaan strategis bersifat adapatif, fleksibel, dan mampu menjawab penyesuaian terhadap perkembangan yang muncul serta dapat memanfaatkan peluang yang ada. Perencanaan strategis dapat menggambarkan pelayanan prima pemerintahan, dalam hal ini pemerintah dan aparat dituntut untuk memberikan pelayanan yang prima, yaitu memberikan kepuasan masyarakat yang merupakan faktor penentu keberhasilan bagi setiap organisasi pemerintah. Oleh karena itu pola-pola pelayanan yang perlu diselenggarakan harus disesuaikan dengan kebutuhan masyarakat. 
$\begin{gathered}\text { Perencanaan } \\ \text { strategis }\end{gathered} \begin{array}{r}\text { dapat } \\ \text { meningkatkan }\end{array}$ komunikasi artinya
implementasi perencanaan strategis akan
dapat memfasilitasi komunikasi dan partisipasi, mengakomodasikan perbedaan kepentingan, dan mendorong proses pengambilan keputusan yang teratur serta keberhasilan pencapaian tujuan. Implementasi perencanaan strategis dapat meningkatkan komunikasi baik vertikal maupun horisontal. Menurut Tribe (1997:114) ada empat langkah strategi pariwisata yang efektif, yaitu: (1) mengutamakan pelanggan; (2) menjadi pemimpin dalam kualitas; (3) mengembangkan inovasi yang radikal; dan (4) memperkuat posisi strategis. Dahuri dalam http://rokhmindahuri.wordpress. com (02 Februari 2009) mengatakan ada lima strategi pengembangan wisata bahari di Indonesia.

Pertama, dalam pengelolaan pariwisata bahari tersebut pemerintah harus mengubah pendekatan dari sistem birokrasi yang berbelit menjadi sistem pendekatan entrepreurial. Pemerintah dituntut untuk tanggap dan selalu bekerja keras dalam melihat peluang dan memanfaatkan peluang sebesar-besarnya untuk kemakmuran rakyat. Pemerintah sebagai pemegang kebijakan harus menyiapkansebuah regulasi/kebijakan yang mendukung pengembangan pariwisata bahari. Kebijakan tersebut antara lain, adalah menciptakan kawasan ekonomi khusus di kawasan yang sedang mengembangkan pariwisata bahari, misalnya memberikan kebijakan bebas visa pada wisatawan asing yang akan berkunjung.

Kedua, melakukan pemetaan terhadap potensi wisata bahari yang dimiliki, berupa nilai, karakteristiknya, infrastruktur pendukungnya, dan kemampuannya dalam menopang perekonomian. Dengan demikian, dapat ditentukan wisata bahari mana yang harus segera dibangun dan mana yang hanya perlu direvitalisasi. Selain itu, juga perlu dipetakan lingkungan yang terkait dengan pariwisata bahari, baik lingkungan internal maupun eksternal. Lingkungan internal yang perlu dipetakan adalah bagaimana kekuatan dan kelemahan pariwisata bahari tersebut. Lingkungan eksternal yang perlu dipetakan adalah sosial-budaya, politikkebijakan, ekonomi-pasar, dan kemampuan teknologi. Selain itu, juga perlu diketahui sejauh mana negara-negara lain melangkah dalam pengembangan pariwisata bahari, Indonesia bisa belajar dari keberhasilan dan kegagalan mereka dalam mengembangkan pariwisata bahari.

Ketiga, menyusun rencana investasi dan pembangunan atas berbagai informasi yang telah didapatkan dari pemetaan di atas. Yang perlu diperhatikan dalam penyusunan ini adalah Indonesia tidak hanya akan membangun sebuah pariwisata bahari. Namun, juga perlu diperhatikan faktor pendukungnya, seperti akses transportasi, telekomunikasi, dan lain-lain. Dengan demikian, rencana pengembangan pariwisata bahari dapat terukur dan tepat sasaran.

Keempat, menciptakan kualitas SDM yang tangguh di bidang pariwisata bahari, baik keahlihannya, kemampuan dalam inovasi, adaptabilitas dalam menghadapi berbagai perubahan lingkungan eksternal, budaya kerja dan tingkat pendidikan, serta tingkat pemahaman terhadap permasalahan strategis dan konsep yang akan dilaksanakannya. Pada masa mendatang keunggulan SDM dalam berinovasi akan sangat penting setara dengan pentingnya SDA dan permodalan. Hal ini terkait dengan perkembangan teknologi yang pesat, khususnya teknologi informasi.

Kelima, melakukan strategi pemasaran yang baik, seperti yang dilakukan Thailand. Thailand memasarkan objek wisatanya di televisi-televisi internasional dan berbagai media massa seperti internet, majalah dan pameran-pameran pariwisata di tingkat internasional. Bahkan, mereka menghabiskan dana sekitar US\$ 1 miliar untuk mempromosikan wisata di beberapa jaringan televisi internasional. Bahkan, beberapa negara melakukan segmentasi pasar wisatawan. Hal ini seperti dilakukan oleh Hongkong dan Thailand untuk memudahkan rencana pengembangan pariwisatanya 
dengan tidak menyamaratakan pasar wisatawan.

\section{PEMBAHASAN \\ Potensi wisata bahari}

Potensi wisata bahari di Indonesia sangat beragam, bahkan nilai keindahannya tiada bandingannya di dunia. Misalnya, Kepulauan Padaido di Papua memiliki taman laut yang indah. Keindahannya bahkan menempati peringkat tertinggi di dunia dengan skor 35. Posisi ini telah mengalahkan taman laut Great Barrier Reef dengan skor 28 di Queensland, Australia. Selain jenis wisata alam (eco tourism) seperti Taman Laut Kepulauan Padaido, masih ada banyak jenis wisata bahari lainnya yang tersebar di Nusantara di antaranya adalah wisata bisnis (business tourism), wisata pantai (seaside tourism), wisata budaya (cultural tourism), wisata pemancingan (fishing tourism), wisata pesiar (cruise tourism), wisata olahraga (sport tourism), dan lain-lain.

Wisata bahari mencakup kegiatankegiatan yang terdiri dari sailing (berlayar), cruising (kapal pesiar), yachting (perahu), diving (penyelaman), snorkeling (penyelaman laut dalam), wind surfing (selancar angin), surfing (selancar), jet ski sport (olahraga jet ski), power boating (perahu bermotor), canoeing (bersampan), sea kayaking (kayak dilaut), boat racing (lomba perahu), whale watching (menonton ikan paus), dan sport fishing (lomba pancing ikan).

Yang perlu dipersiapkan untuk kegiatan wisata bahari adalah (1) penyiapan sarana prasarana; (2) pelaku pengelola dan pelaksana; c) aksesibilitas ke produk dan destinasi wisata bahari; dan d) pedagang perantara atau tour operator. Wisata Bahari itu memerlukan pelayanan publik berupa: (1) SDM penjaga pantai yang andal; (2) SAR yang siap sedia; (3) peralatan keselamatan
/ kendaraan di darat sampai helikopter; (4) peraturan-peraturan/urusan keselamatan, keamanan yang berstandar internasional; dan e) sejumlah hal teknis lainnya.

Pemerintah sebagai pendukung dan fasilitator tetap berada di garis depan dengan memfasilitasi pengembangan sarana dan prasarana, kegiatan pendidikan, dan pemasaran wisata bahari.

\section{Identifikasi dan sebaran wisata bahari Kabupaten Ende}

Terdapat 15 lokasi wisata budaya dan 69 lokasi wisata alam yang tersebar pada 21 kecamatan di Kabupaten Ende dan yang menjadi lokasi wisata bahari terdapat di 24 lokasi yang tersebar di 11 kecamatan. Jumlah itu siap dikembangkan menjadi daya tarik bagi wisatawan seperti terlihat pada Tabel 2 . Dari Tabel 2 dan Lampiran 3 dan Lampiran 4 dapat dilihat bahwa semua objek wisata bahari belum dikembangkan. Yang disuguhkan sebagai objek wisata masih berupa panorama saja.

\section{Issue utama wisata bahari Kabupaten Ende}

Yang menjadi isu utama dalam pengembangan wisata bahari di Kabupaten Ende adalah (1) ancaman terhadap biota laut berupa pengeboman dan perusakan terumbu karang oleh masyarakat setempat; (2) pencarian ikan dengan cara pemboman yang dilakukan oleh nelayan tradisional agar cepat mendapatkan hasil malah merusak dan menghancurkan biota laut yang ada. Pencegahan yang dilakukan oleh aparat kepolisian setempat pada saat ini terasa terlambat karena telah rusaknya biota laut yang merupakan keindahan dari kekayaan bahari Pulau Flores. 
Tabel 2

Objek Wisata Bahari di Kabupaten Ende

\begin{tabular}{|c|c|c|c|c|}
\hline No & Nama Tempat Wisata & Kecamatan & Kelurahan/Desa & Objek \\
\hline 1 & Pantai Mbu'u & Ndona & Naganesa & \begin{tabular}{|l} 
Matahari Terbenam, \\
Pemandian dan rekreasi \\
\end{tabular} \\
\hline 2 & Pantai Nanganesa & Ndona & Desa Naganesa & Panorama \\
\hline 3 & Tanjung Ngalu Tengah & Wolojita & Wolojita & $\begin{array}{l}\text { Pantai Berkarang tempat } \\
\text { dilaksanakan upacara adat } \\
\text { meminta hujan }\end{array}$ \\
\hline 4 & Gua Kelelawar Lia Ngighi & \begin{tabular}{|l} 
Lio Timur \\
Wewaria
\end{tabular} & Hobatuwa & Panorama Kelelawar \\
\hline 5 & Pantai Ropa & Pualu Ende & Desa Keliwumbu & Panorama \\
\hline 6 & Pantai Ekoreko/Ngazu Kapu & Pualu Ende & Desa Rorurangga & Panorama \\
\hline 7 & Pantai Pu Utara & Pualu Ende & Desa Puutara & Panorama \\
\hline 8 & Pantai Aejeti & Pualu Ende & Desa Aejeti & Panorama \\
\hline 9 & Pulau Songo & Pualu Ende & Desa Aejeti & Panorama \\
\hline 10 & Pantai Matinumba & Pualu Ende & Desa Ndoriwoy & Panorama \\
\hline 11 & Pantai Penggajawa & Nagapanda & Nggorea & \begin{tabular}{|l|} 
Panorama, Matahari \\
Terbenam dan Batu \\
Berwarna \\
\end{tabular} \\
\hline 12 & Pantai Nangapanda & Nagapanda & & Panorama \\
\hline 13 & Pantai Nangamboa & Nagapanda & & Panorama \\
\hline 14 & Pantai Nggemo-Jaga Po & Maukaro & Desa Kobaleba & Panorama \\
\hline 15 & Pulau Karang Putih & Maukaro & Nabe & $\begin{array}{l}\text { Panorama dan Tempat } \\
\text { Pemandian }\end{array}$ \\
\hline 16 & Pantai Mausambi & Maurole & Desa Mausambi & Panorama \\
\hline 17 & Pantai Maurole & Maurole & Desa Maurole & Panorama \\
\hline 18 & Pantai Enabara & Maurole & Desa Nanganio & Panorama \\
\hline 19 & Pantai Loboniki & Kotabaru & Desa Loboniki & Panorama \\
\hline 20 & Pantai Tou & Kotabaru & Desa Tou & Panorama \\
\hline 21 & Pantai Ngalutora & Kotabaru & & Panorama \\
\hline 22 & Tanjung Watumanu & Kotabaru & Kota Baru & \begin{tabular}{|l|} 
Panorama Matahari \\
Terbenam dan Matahari \\
Terbit
\end{tabular} \\
\hline 23 & Pantai Pelabuhan Ende & Ende Utara & \begin{tabular}{|l|} 
Kotaratu dan \\
kotaraja
\end{tabular} & $\begin{array}{l}\text { Panorama dan Matahari } \\
\text { Terbenam }\end{array}$ \\
\hline 24 & Pantai Bita & Ende Timur & mautapaga & $\begin{array}{l}\text { Panorama dan Matahari } \\
\text { Terbenam }\end{array}$ \\
\hline
\end{tabular}

Dinas Kebudayaan dan Pariwisata Kabupaten Ende, 2011

\section{Abrasi Pantai}

Pesisir pantai Kabupaten Ende lebihlebih disisi selatan terjadi abrasi disebabkan penambangan pasir besi dan batu berwarna Penggajawa yang dilakukan tanpa memperhatikan pelestarian lingkungan.
Kebijakan yang belum sempurna dan belum berpihak kepentingan wisata

Pemerintah Kabupaten Ende dalam perencanaan pembangunan belum mengalokasikan secara cukup anggaran untuk pariwisata. Hal ini dapat dilihat pada Tabel 3 berikut. 
Dari tahun 2007 sampai dengan tahun 2010 alokasi belanja pada sektor pariwisata adalah sebagai berikut pada tahun 2007 sebesar 1,54\% dari belanja daerah, tahun 2008 sebesar 0,72\% dari belanja daerah, tahun 2009 sebesar 0,54\% dari belanja daerah, tahun 2010 sebesar $0,49 \%$ dari belanja daerah. Jadi, secara rata-rata paling banyak sektor kebudayaan dan pariwisata mendapat persentase terbesar dari belanja daerah adalah pada tahun 2007 yaitu lebih besar dari 1\%. Dari alokasi yang ada tidak semua dialokasikan kepada sektor pariwisata karena Dinas Kebudayaan dan Pariwisata Kabupaten Ende mempunyai 2 sektor yang menjadi tugasnya yaitu sektor kebudayaan dan sektor pariwisata.

Tabel 3

Belanja Daerah Kabupaten Ende dan Alokasi Belanja Pada Dinas Kebudayaan dan Pariwisata

Kabupaten Ende Tahun Anggaran 2007-2010

\begin{tabular}{|c|c|c|c|}
\hline$\dot{z}$ & 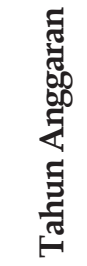 & Alokasi Dana & Belanja Daerah \\
\hline 1 & 2007 & Rp. 5.260.655.027 & Rp. 340.723.001.207 \\
\hline 2 & 2008 & Rp. 3.347.504.000 & Rp. 462.275.354.571 \\
\hline 3 & 2009 & Rp. 2.462.185.943 & Rp. 451.121.812.291 \\
\hline 4 & 2010 & Rp. 2.474.741.335 & Rp. 508.319.170.215 \\
\hline
\end{tabular}

Kabupaten Ende, 2011

\section{Strategi dan Pengembangan Wisata Bahari Ende ke Depan}

Berangkat dari paparan di atas, maka dapat dirumuskan beberapa solusi startegi dari persoalan wisata bahari di Ende.

Pertama, untuk dapat mengelola potensipotensi wisata bahari yang ada, Pemerintah Kabupaten Ende harus mengeluarkan kebijakan yang memberikan kesempatan dan kemudahan kepada pelaku pariwisata untuk dapat masuk ke dalam kawasan wisata bahari agar memulai usahanya. Kebijakan yang dilakukan adalah dengan mempermudah pengurusan izin usaha dan izin mengelola kawasan wisata bahari. Kebijakan pemerintah yang terkait dengan strategi ini adalah kebijakan penataan ruang dengan mengikuti peraturan yang berlaku dan perlindungan terhadap lingkungan.

Kedua, pemerintah membuat perencanaan untuk mengembangkan kawasankawasan wisata bahari sehingga dapat diketahui kawasan mana yang lebih dapat cepat dijual dan kawasan mana yang perlu lebih banyak memerlukan penataan infrastruktur. Strategi kedua ini ditempuh agar tidak terjadi konflik kepentingan antarsektor. Sebagian besar masyarakat pesisir pantai adalah nelayan sekaligus petani.

Ketiga, dengan perencanaan yang dibuat dalam strategi kedua, akan dapat diketahui bukan saja apa yang harus dikembangkan di kawasan wisata bahari, tetapi juga akan diketahui hal apa saja yang diperlukan untuk sarana-sarana pendukung kawasan wisata bahari di Kabupaten Ende. Yang penting diperhatikan di Kabupaten Ende adalah pengembangan sarana pelabuhan laut Dermaga Ende dan Dermaga Ippi sehingga bisa disandari oleh kapal-kapal pesiar yang besar dan penambahan kemampuan Bandar Udara H.H. Aroeboesman Ende untuk bisa didarati pesawat berbadan lebar. Selain itu, juga dukungan infrastruktur jalan yang menghubungkan potensi-potensi wisata bahari di Kabupaten Ende. Dukungan infrastruktur yang baik akan mempermudah masuknya wisatawan ke daerah wisata dalam hal ini daerah wisata bahari.

Keempat, pemerintah bersama masyarakat kawasan wisata bahari mempersiapkan sumber daya manusia yang akan mengelolanya. Pengembangan sumber daya manusia bisa dilakukan melalui pelatihan-pelatihan pengelolaan wisata bahari. Melalui strategi ini diharapkan masyarakat dapat berpartisipasi dalam pengembangan wisata bahari. Masyarakat setempat diharapkan menjadi pengelola objek wisata bahari di daerah mereka sendiri. Sebagian daya tarik wisata di Kabupaten Ende belum ditata dan dikelola dengan baik. 
Jalan masuk yang belum memadai, belum adanya MCK, belum adanya papan penunjuk lokasi, sampah dibiarkan berserakan, belum terpeliharanya kebersihan lingkungan, serta belum adanya petugas pengelola yang dapat bekerja secara profesional.

Kelima, pemerintah mempromosikan kawasan-kawasan wisata bahari di Kabupaten Ende secara kontinu dan berkesinambungan melalui berbagai cara dan media. Promosi yang dilakukan dapat melalui media online yaitu melalui web milik Pemda Ende dan mengikuti pameranpameran yang diselenggarakan oleh pemerintah pusat atau pemerintah daerah lain bahkan negara-negara lain sehingga wisatawan baik wisatawan nusantara maupun wisatawan asing mulai mengenal potensi wisata bahari Ende.

Kelima strategi ini diharapkan dapat mengembangkan potensi pariwisata bahari di Kabupaten Ende. Namun, strategi-strategi ini tidak akan berarti jika pemerintah, investor/swasta, perbankan, masyarakat, dan pihak lain yang berkompeten tidak berkoordinasi dalam mengembangkan potensi wisata bahari untuk kemakmuran rakyat Kabupaten Ende.

\section{SIMPULAN}

Objek wisata bahari di Kabupaten Ende belum dikembangkan. Hal ini disebabkan perhatian pemerintah terhadapnya melalui APBD (Anggaran Pendapatan dan Belanja Daerah)Kabupaten Endekurang. Diharapkan Dinas Kebudayaan dan Pariwisata Kabupaten Ende bekerja sama dengan berbagai pihak yang terkait mengembangkan objek wisata bahari dengan mengutamakan partisipasi masyarakat setempat. Anggaran yang ada agar dimanfaatkan untuk pengembangan promosi wisata bahari agar kunjungan wisatawan menjadi satu kesatuan dengan kunjungan ke Danau Tri Warna Kelimutu.

Agar pengembangan potensi wisata ini maksimal, infrastruktur dan manajemennya diatur sebelum dipromosikan. Hal ini mencegah terjadinya dampak negatif dari pengembangan sektor pariwisata. Wisatawan menjadi kecewa dengan promosi yang ada tidak sesuai kondisi rill dilapangan. Ratarata prasarana jalan ke objek wisata bahari buruk sehingga kenyamanan wisatawan menjadi tertanggu.

Pemerintah perlu mendorong masyarakat agar pengelolaan wisata bahari dapat berkembang dengan cara melakukan pelatihan atau workshop sehingga sumber daya manusia untuk mengelola pariwisata dapat meningkat ke arah yang lebih baik. Pada akhirnya akan berakibat kepada kesejahteraan masyarakat sendiri. Masyarakat di daerah tujuan wisata dapat merasakan manfaat dari pengembangan objek wisata bahari.

\section{DAFTAR PUSTAKA}

Abdul Karim, S, 15 Januari 2009, "Strategi Pengembangan Dan Pemasaran Pariwisata Di Daerah Kurang Berkembang," dalam SumbawaNews.com.

Baiquni, M. 2004, “Manajemen Strategis," Buku Ajar, Yogyakarta: Pusat Studi Kajian Pariwisata Sekolah Pascasarjana Universitas Gadjah Mada.

Cempora, E, 2007, "Pola Spasial Pergerakan Wisatawan Di Kabupaten Pacitan," Tesis (Tidak Dipublikasikan), Yogyakarta: Magister Kajian Pariwisata Sekolah Pascasarjana Universitas Gadjah Mada.

Dahuri, R, 2 Februari 2009, "Strategi Pengembangan Pariwisata Bahari" dalam http://rokhmindahuri. wordpress.com.

Dinas Kebudayaan dan Pariwisata Kabupaten Ende, 2011, Data Objek dan Daya Tarik Wisata Kabupaten Ende, Ende: Dinbudpar.

Fandeli, C, 1995, Dasar-dasar Kepariwisataan Alam, Yogyakarta: Penerbit Liberty.

1996, Pengusahaan Ekowisata, Yogyakarta: Pustaka Pelajar. 
Fandeli, C dan Muchlison, 2000, Pengusahaan Ekowisata, Yogyakarta: Fakultas Kehutanan UGM.

Gadi Djou, J. A., 2011, Strategi Pengembangan Potensi Wisata Bahari di Kabupaten Ende, Jurnal Kepariwisatan Indonesia.

Gunn, C. A., 2002, Tourism Planning: Basics Concepts Cases, Fourth Edition. Routledge. New York.

Gunawan, M. P., dan Herliana, I, 2000, Garis Besar Perencanaan Pengembangan dan Pemasaran Pariwisata di Tingkat Lokal dan Wilayah, Bandung: Pusat Penelitian Kepariwisataan ITB.

Hermantoro, H, 2009, Pengelolaan Bidang Pariwisata Bahari dalam Pelaksanaan Strategi Adaptasi Terhadap Dampak Perubahan Iklim. Jurnal Kepariwisataan Indonesia. Vol. 4, No. 1.

Kompas, 6 Juni 2011, “Tugas Besar Di Balik Keindahan Alam Flores," Jakarta: Kompas.
Marpaung, F, 2009. Strategi Pengembangan Kawasan Sebagai Sebuah Tujuan Wisata: Studi Kasus Pasar Seni Gabusan di Kabupaten Bantul, Tesis S-2 tidak dipublikasikan, Yogyakarta: Magister Kajian Pariwisata Sekolah Pascasarjana UGM.

Marpaung, H, 2002, Pengetahuan Kepariwisataan, Cetakan Kedua, Edisi Revisi, Bandung: Alfabeta.

Mill, C. R., dan Morrison M. A., 1985, The Tourism System, An Introductory Text. New Jersey: Prentice Hall Inc.

Pearce, D, 1989, Tourist Development, Second Edition, New York: Longman Grup Limited.

Tribe, J, 1997, Corporate Strategy for Tourism, Boston: Intenational Thomson Bussiness Press.

Wardiyanto dan Baiquni, M., 2011, Perencanaan dan Pengembangan Pariwisata, Bandung: Lubuk Agung. 